\title{
Grain Boundary Precipitates and Mechanical Properties of Alloy 706
}

\author{
O.Matsumoto, T. Honjo, Y.Yasumoto, T.Moriyama and T.Tsuchiyama
}

Kobe Steel Co. LTD.

2-3-1, Shinhama, Araicho, Takasago-shi, Hyougo-ken 676 Japan

\begin{abstract}
Effects of cooling rate from solution treatment temperature on mechanical properties and microstructures of a large Alloy 706 disk forging has been investigated.

The precipitation of delta and eta phases occured at the grain boundaries with a increase of cooling rate from solution treatment temperature.

The morphology changes of from globular type to cellular type and coarsening of precipitates were observed with decresing the cooling rate. The mechanical properties at room temperature such as yield strength, tensile strength, elongation, reduction in area and absorbed energy increased with increasing the cooling rate from solution treatment temperature.

Same tendency was observed in the yield and tensile strength at elevated temperatures, although ductilities at $650{ }^{\circ} \mathrm{C}$ slightly decreased with incresing the cooling rate.

Creep rupture time at $650{ }^{\circ} \mathrm{C}$ under $690 \mathrm{MPa}$ extended with increasing the cooling rate from solution treatment, while creep rupture ductility decreased with increasing cooling rate.

These results were closely associated with the precipitation behavior of delta and eta phases at grain boundaries.
\end{abstract}

\section{Introduction}

Current Alloy 706 has been used for a heavy duty industrial gas turbine. ${ }^{12,2)}$ In Alloy 706, there are two types of aging treatment, originally developed by International Nickel Company. ${ }^{3)}$ A three-step aging process is used for application where high temperature creep rupture ductility is required, and a two-stepaging process is emploied when tensile and impact properties are required. In general, Alloy 706 for a gas turbine disk has been used at the temperature ranges lower than creep temperature range, therefore the two-step aging process has been applied. Since a large forging such as a gas turbine disk has a heavy thicknessof more than $300 \mathrm{~mm}$, the cooling rates from solution treatment temperature differ with locations, and they affects the mechanical properties.

This paper describes the effect of cooling rate from solution treatment temperature in relation to microstructures and mechanical properties including creep rupture properties. 
Table I Chemical compositions of Alloy 706 used (wt \%)

\begin{tabular}{|c|cccccccccccc|}
\hline Alloy & $C$ & $\mathrm{Si}$ & $\mathrm{Mn}$ & $\mathrm{P}$ & $\mathrm{S}$ & $\mathrm{Ni}$ & $\mathrm{Cr}$ & $\mathrm{Ti}$ & $\mathrm{Al}$ & $\mathrm{Nb}$ & $\mathrm{B}$ & $\mathrm{Fe}$ \\
\hline $\mathrm{A}$ & 0.016 & 0.10 & 0.27 & 0.004 & 0.004 & 40.03 & 16.02 & 1.57 & 0.28 & 3.07 & 0.0030 & $\mathrm{Bal}$ \\
$\mathrm{B}$ & 0.008 & 0.09 & 0.07 & 0.006 & 0.001 & 41.19 & 15.81 & 1.66 & 0.15 & 2.82 & 0.0033 & $\mathrm{Bal}$ \\
\hline
\end{tabular}

Table II Simulated heat treament of Alloy 706 used

\begin{tabular}{ll}
\hline Solution treatment & $: 990^{\circ} \mathrm{C}-3 \mathrm{~h}$ \\
Cooling rate & $: 1050,580,240,100,20^{\circ} \mathrm{C} / \mathrm{h}$ \\
Aging & $: 730^{\circ} \mathrm{C}-10 \mathrm{~h} /$ furnace cool to $620^{\circ} \mathrm{C}$ \\
& $620^{\circ} \mathrm{C}-8 \mathrm{~h} /$ air cool \\
\hline
\end{tabular}

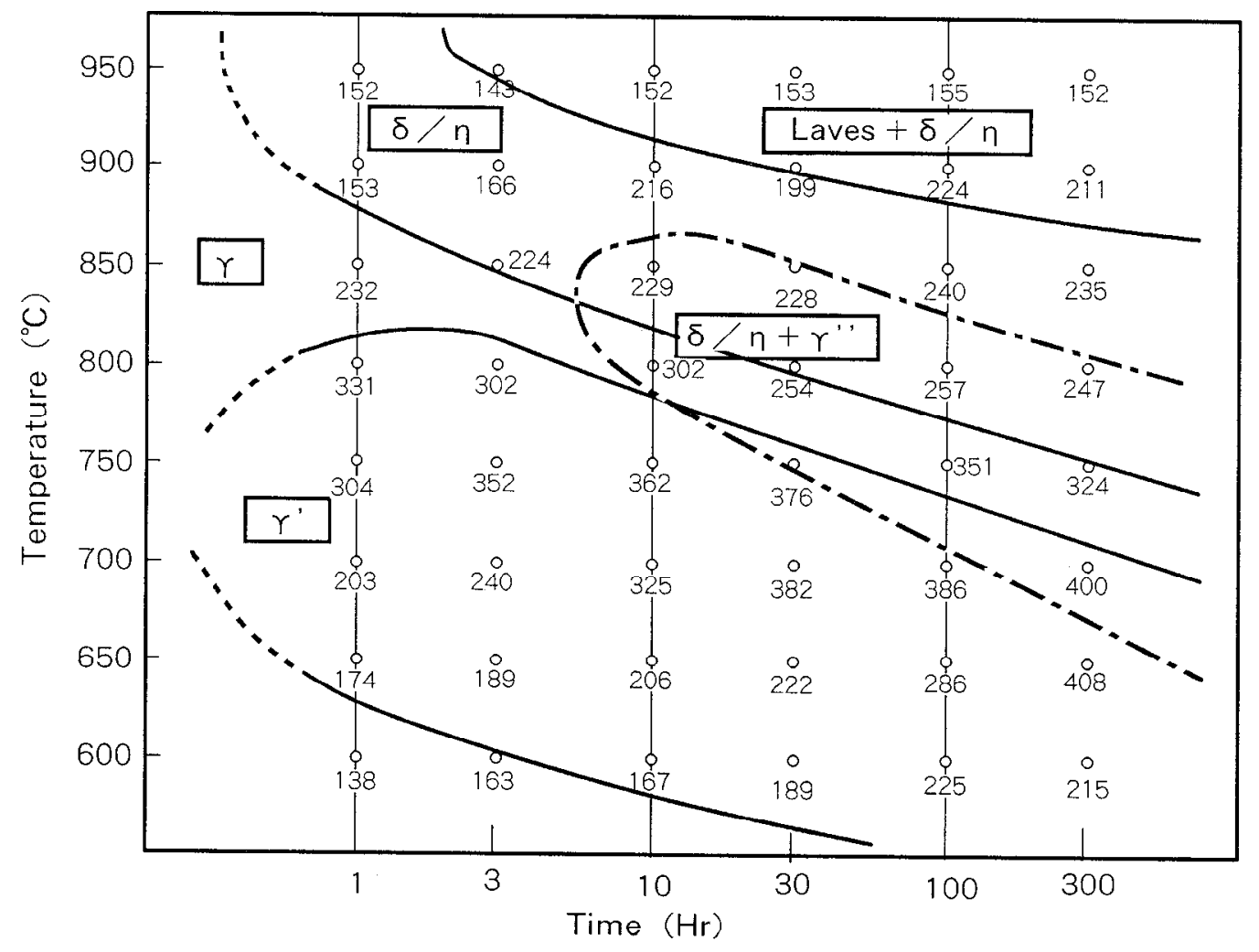

Figure 1 TTT diagram and Vickers hardness of Alloy 706 


\section{Material and Experimental Procedure}

Chemical compositions of the materials are shown in Table I.

Alloy A was a small ingot weighting about $1000 \mathrm{~kg}$ which was melted by a induction furnace and electroslag remelting(ESR). After melting, the ingot was forged and heat treated subsequently was subjected to tests for the TTT diagram. Alloy B was taken from rim portion of a large disk forging with $1900 \mathrm{~mm}$ in diameter and $310 \mathrm{~mm}$ in thickness ${ }^{4)}$. The disk was made by a 10 ton ingot which was melted by a vacuum ladle refining and ESR process followed by forging operation using a 13000 ton capacity press. After forging, the rim material was removed from the disk to study the effect of cooling rate from solution treatment temperature. The simulated heat treatments shown in Tablell were emploied to the test blocks. Tensile andCharpy impact tests were carried out at room temperature. High temperaturetensile tests were performed at temperatures of up to $650^{\circ} \mathrm{C}$. Creep rupture test at $650{ }^{\circ} \mathrm{C}$ under $690 \mathrm{MPa}$ was conducted using combination (smooth and notched) specimens. Microstrucral study of the various specimens was conducted using optical, scanning electron and transmission electron microscopies.

\section{Results and Discussion}

\section{Time-Temperature Transformation}

Prior to study the effects of cooling rate on mechanical properties, the precipitation behavior of Alloy 706 was studied.

The time-temperature-transition (T-T-T) behavior was studied by SEM/EDX, and optical microscopy and hardness for Alloy A.

Test specimens were solution treated at $990{ }^{\circ} \mathrm{C}$ followed by rapid quenching and aged at various temperatures.

Figure 1 shows T-T-T diagram and hardness of Alloy 706. Present T-T-T diagram is similar to previous reports ${ }^{3)}$.5). Laves, delta, eta, ganma prime, and ganma double prime were observed in this work. Peak hardness was observed at around $700{ }^{\circ} \mathrm{C}$. Coarsed delta and/or eta precipitates exsist over $800{ }^{\circ} \mathrm{C}$ and it leads to decrese in hardness.

\section{Effect of cooling rates on microstructure}

Figure 2 shows SEM photographs of as solution treated microstructure with different cooling rates from solutioning temperature of $990{ }^{\circ} \mathrm{C}$ for Alloy 706 . It was found that the amount and size of precipitates at grain boundaries increase with decreasing cooling rate. The preciitation of eta and delta phases predominatly occured to grain boundaries on the way to cooling from solutioning temperature.

These intergranular precipitates become larger as the cooling rate become slower, and these seem to be grown eta and delta phases.

Figure 3 shows SEM photographs of the Alloy 706 which was cooled with various rates from solution temperature of $990^{\circ} \mathrm{C}$ and aged. In comparison with the microstructures shown in Figure 2, the finer $r^{\prime}$ and $r^{\prime}$ 'phases which precipitated by aging were observed within grains.

Figure 4 shows TEM photographs and analysis results by EDX of the alloy which 

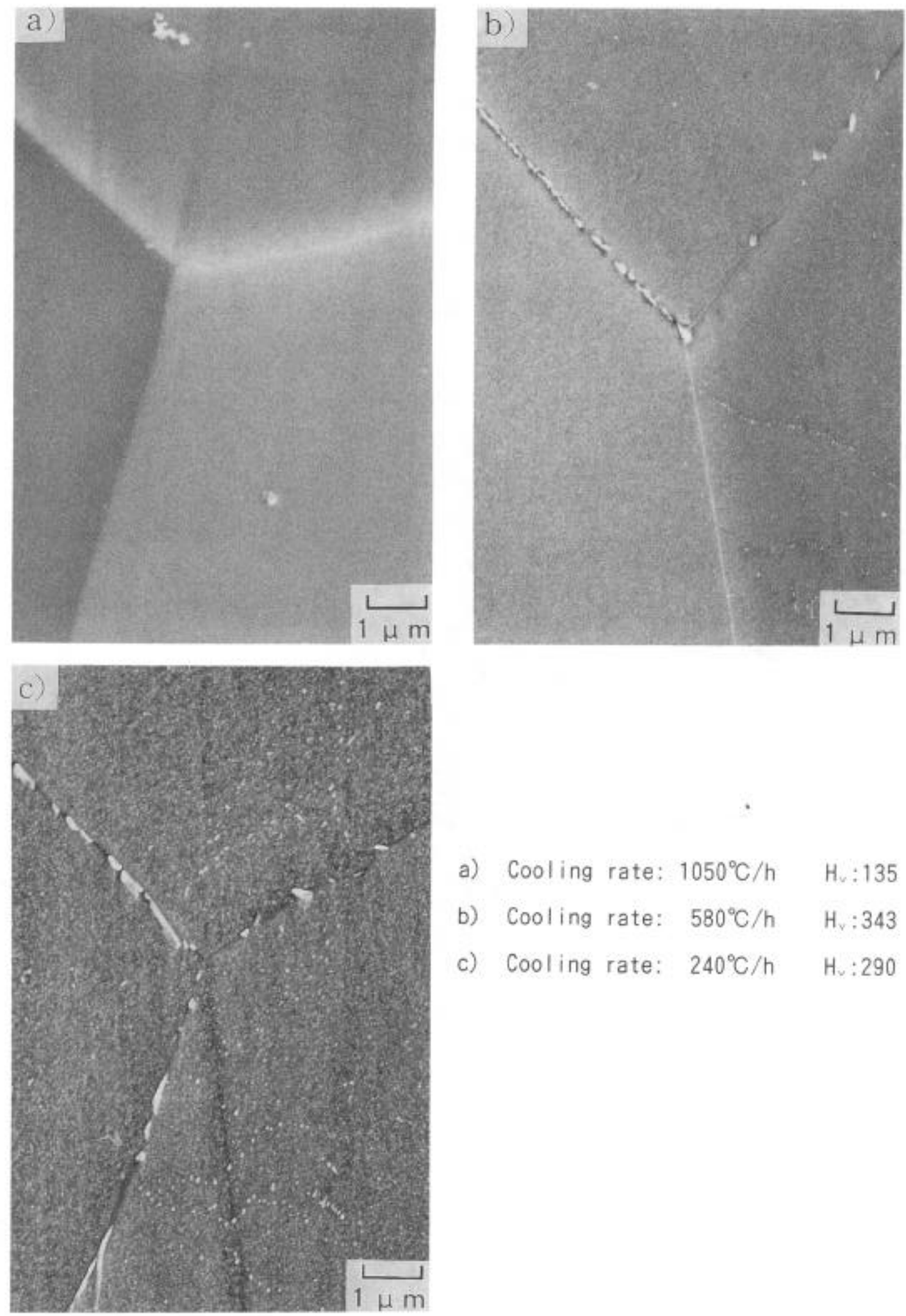

a) Cooling rate: $1050^{\circ} \mathrm{C} / \mathrm{h} \quad \mathrm{H}_{v}: 135$

b) Cooling rate: $580^{\circ} \mathrm{C} / \mathrm{h} \quad \mathrm{H}_{\mathrm{v}}: 343$

C) Cooling rate: $240^{\circ} \mathrm{C} / \mathrm{h} \quad H_{v}: 290$

Figure 2 Scanning electron micrographs of as solution treated specimens cooled with various rates from solution temperature in Alloy 706 392 

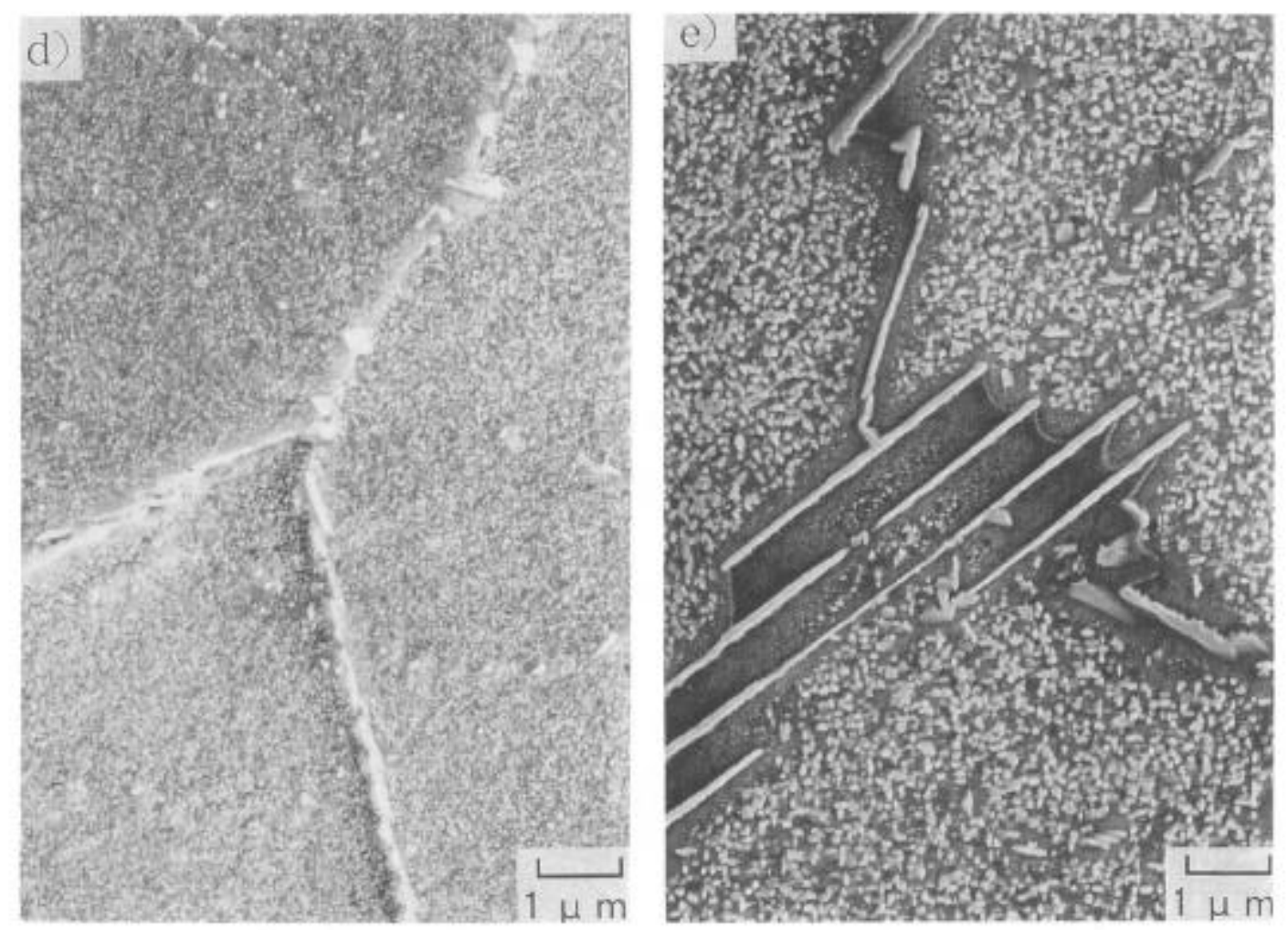
d) Cooling rate:
$100^{\circ} \mathrm{C} / \mathrm{h}$
$H_{v}: 344$
e) Cooling rate:
$20^{\circ} \mathrm{C} / \mathrm{h}$
$\mathrm{H}_{\mathrm{x}}: 337$

Figure 2 Scanning electron micrographs of as solution treated specimens (continue) cooled with various rates from solution temperature in Alloy 706 

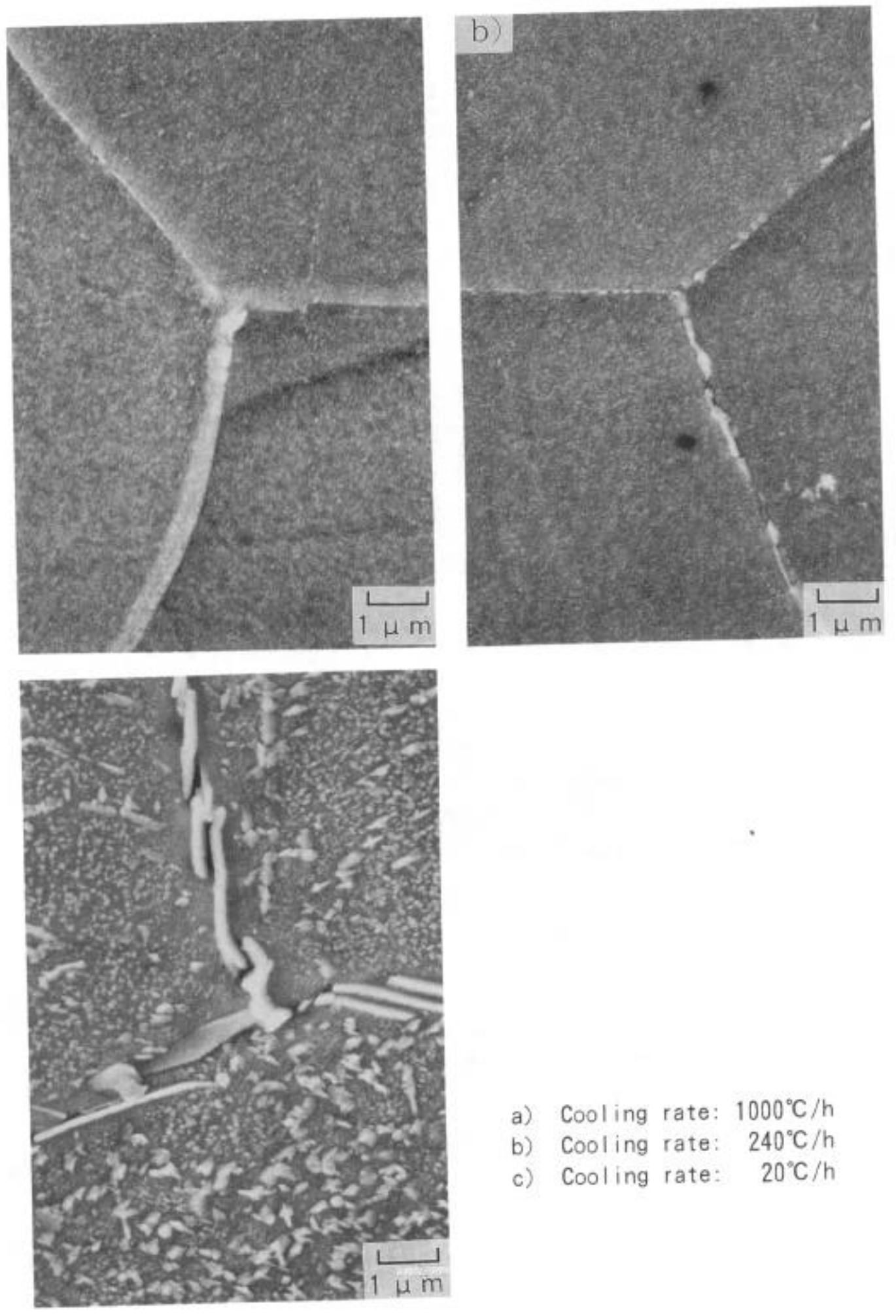
a) Cooling rate: $1000^{\circ} \mathrm{C} / \mathrm{h}$
b) Cooling rate: $240^{\circ} \mathrm{C} / \mathrm{h}$
c) Cooling rate: $20^{\circ} \mathrm{C} / \mathrm{h}$

Figure 3 Scanning electron micrographs of specimens cooled with various rates from solution temperature and aged in Alloy 706 


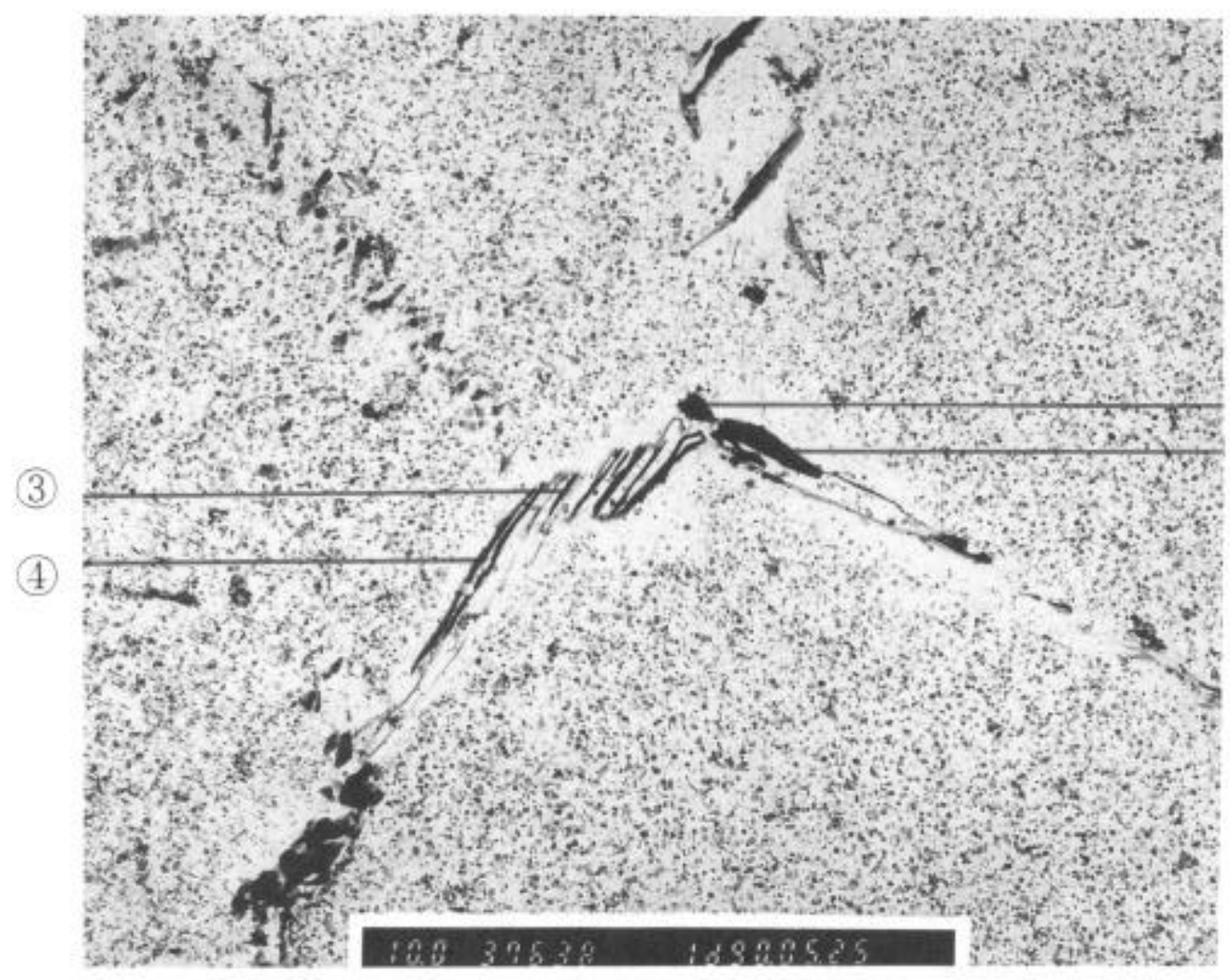

(1)

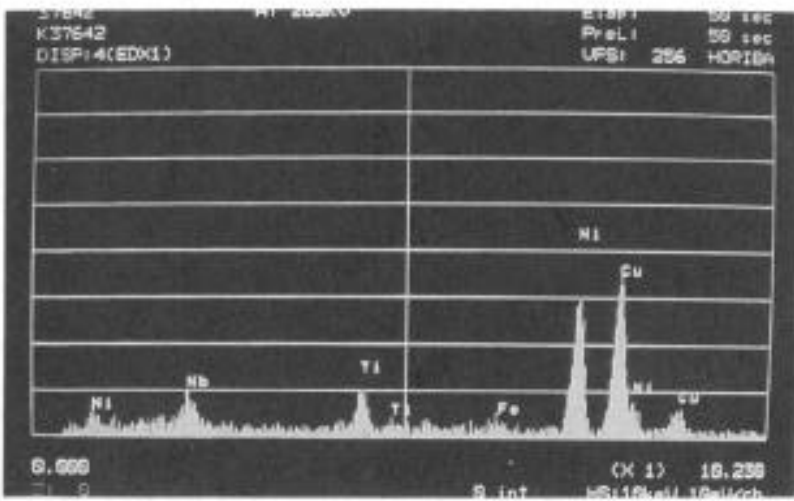
Precipitates (1) and
(4) are seemed to be eta phase.
Precipitates (2) and
(3) are seemed to be del ta phase.

Figure 4 Transmission electron micrograph and EDX analysis of specimens cooled with $100^{\circ} \mathrm{C} / \mathrm{h}$ from solution temperature and aged 
(2)

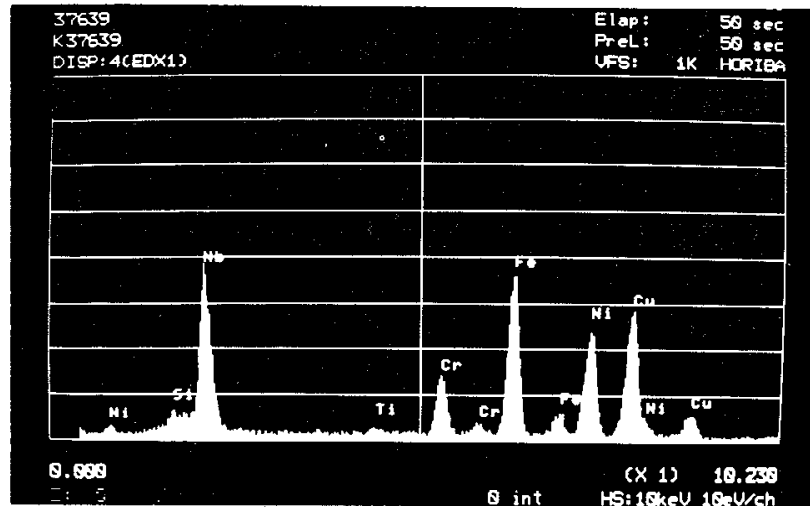

(3)

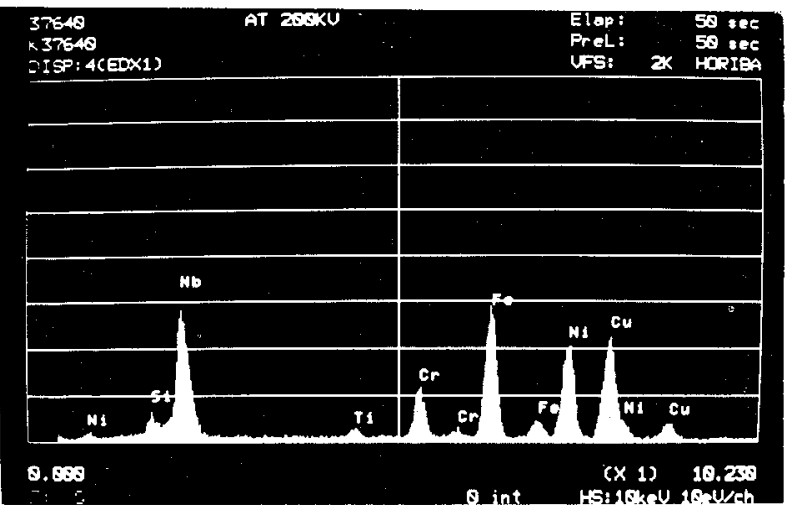

(4)

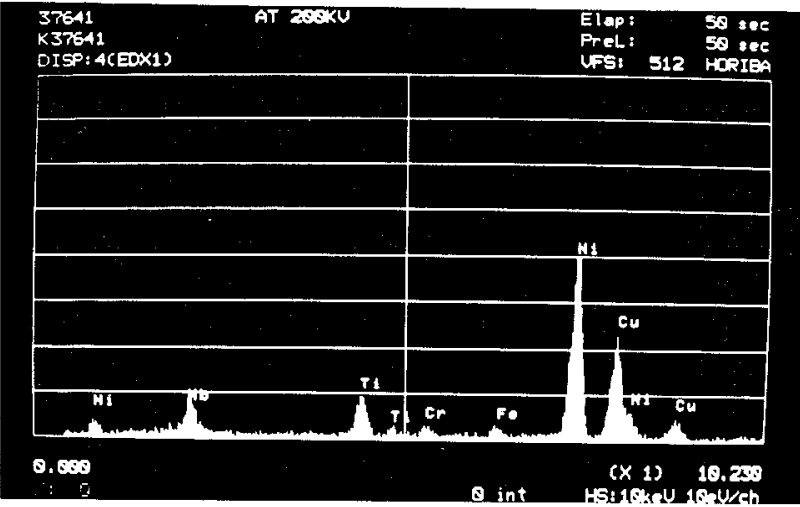

Figure 4 Transmission electron micrograph and EDX analysis of specimens (continue) cooled with $100^{\circ} \mathrm{C} / \mathrm{h}$ from solution temperature and aged 
was cooled at the rate of $100{ }^{\circ} \mathrm{C} / \mathrm{h}$ from solution treatment temperature and aged. It appears that the precipitates which are present at grain boundaries are del ta and eta phases from above result and Heck's result. ${ }^{6)}$

\section{Tensile and Impact Properties}

Mechanical properties were studied to the Alloy 706 with various cooling rates shown in Tablell. The grain size of the specimens which was subjected to solutioning and aging treatments was 3 in ASTM GS No.

Tensile and Charpy impact tests were performed at room temperature and the elevated temperature tensile tests were performed at $482^{\circ} \mathrm{C}$ and $650^{\circ} \mathrm{C}$ on different cooling rates from solution treatment temperature followed by aging.

The effect of cooling rate on tensile and Charpy impact properties at room temperature are shown in Figure 5

The $0.2 \%$ yield strength and tensile strength at room temperature increase with incresing cooling rate. In addtion, small amount of increase in elongation, reduction of area and Charpy absobed energy were recognized.

Tensile properties at $482{ }^{\circ} \mathrm{C}$ and $650^{\circ} \mathrm{C}$ on various cooling rates are shown in Figure 6 . The $0.2 \%$ yield strength and tensile strength exhibited same tendency with room temperature propeties. There are no effects of cooling rate on the ductilities at $482^{\circ} \mathrm{C}$. On the other hand, those at $650^{\circ} \mathrm{C}$ slightly decrease with increasing cooling rate. The degradation cause of $650^{\circ} \mathrm{C}$ tensile ductility is because fine precipitation takes place during the tensile test and it strengthens the grains.

\section{Creep Rupture Properties}

Figure 7 shows creep rupture properties at $650^{\circ} \mathrm{C}$ under $690 \mathrm{MPa}$ on the different cooling rates from solution temperature. Creep rupture time extended and rupture ductility decreased with increasing cooling rate. Notch detriodation are found in case of the cooling rate which exceeds $300{ }^{\circ} \mathrm{C} / \mathrm{h}$. The cooling rate which shows good balance of creep strength and creep ductility is $50 \sim 200{ }^{\circ} \mathrm{C} / \mathrm{h}$ in average. As shown in Figure 3, no grain boundary precipitation occur during cooling from solution treatment temperature at the cooling rate of $1050^{\circ} \mathrm{C} / \mathrm{h}$ and conseguently, precipitation elements such as $\mathrm{Nb}$ and $\mathrm{Ti}$ are keeping in the matrix without precipitation. Thus the coherent and fine precipitation into grains occured during aging. The grains aretherefore strengthen more greater than the grain boundaries. As a result, the grains are difficult to deform and results in brit tle fracture from triple pointof grain boundary.

The globular eta and delta phases are present in the case of cooling rate of $240{ }^{\circ} \mathrm{C} / \mathrm{h}$. The size of precipitates was approximately less than $0.3 \mu \mathrm{m}$ in diameter. This precipitation behavior caused a rise of rupture ductility. The microstructure of the material with a cooling rate of $20^{\circ} \mathrm{C} / \mathrm{h}$, which provides the lowest creep rupture strength showed the film and cellular eta and delta phases at the grain boundaries and the coarse precipitates in grains are present. The precipitates grew from globular type to cellular typeand became coarse with in cresing cooling rate. The precipitation of coarse andstable eta and delta resulted in a small amount of coherent $r$ ' and $r$ 'precipitates and the denuded zone was formed near the grain boudaries. ${ }^{7)}$ Grain size of the present test 


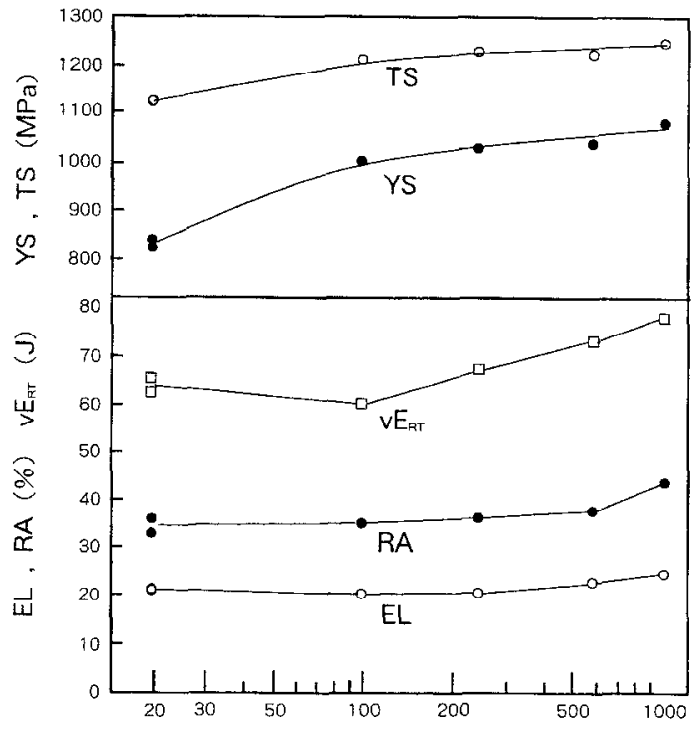

Cooling Rate from Solution Treatment $\left({ }^{\circ} \mathrm{C} / \mathrm{min}\right)$

Figure 5 Room temperature mechanical properties with various cooling rate of Alloy 706

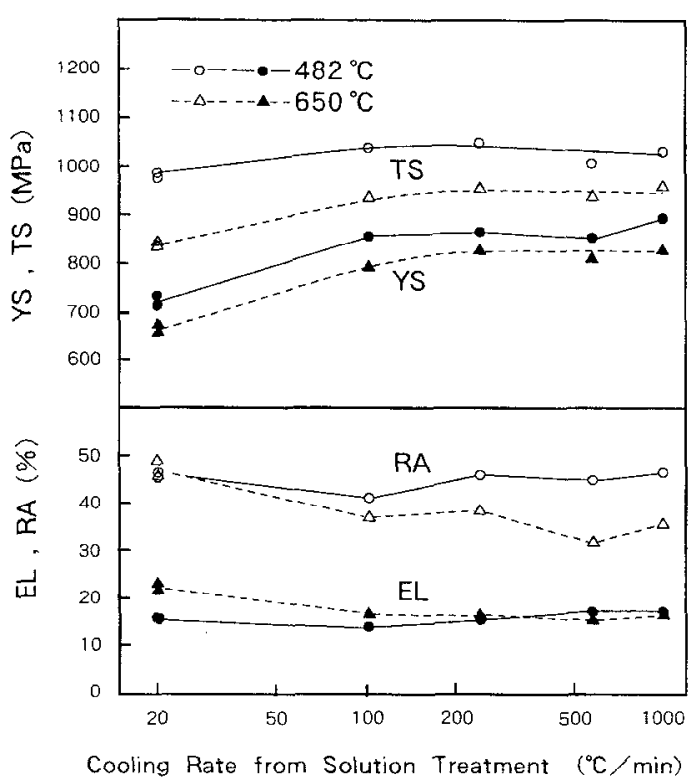

Figure 6 Elevated temperature tensile properties with various cooling rate of Alloy 706

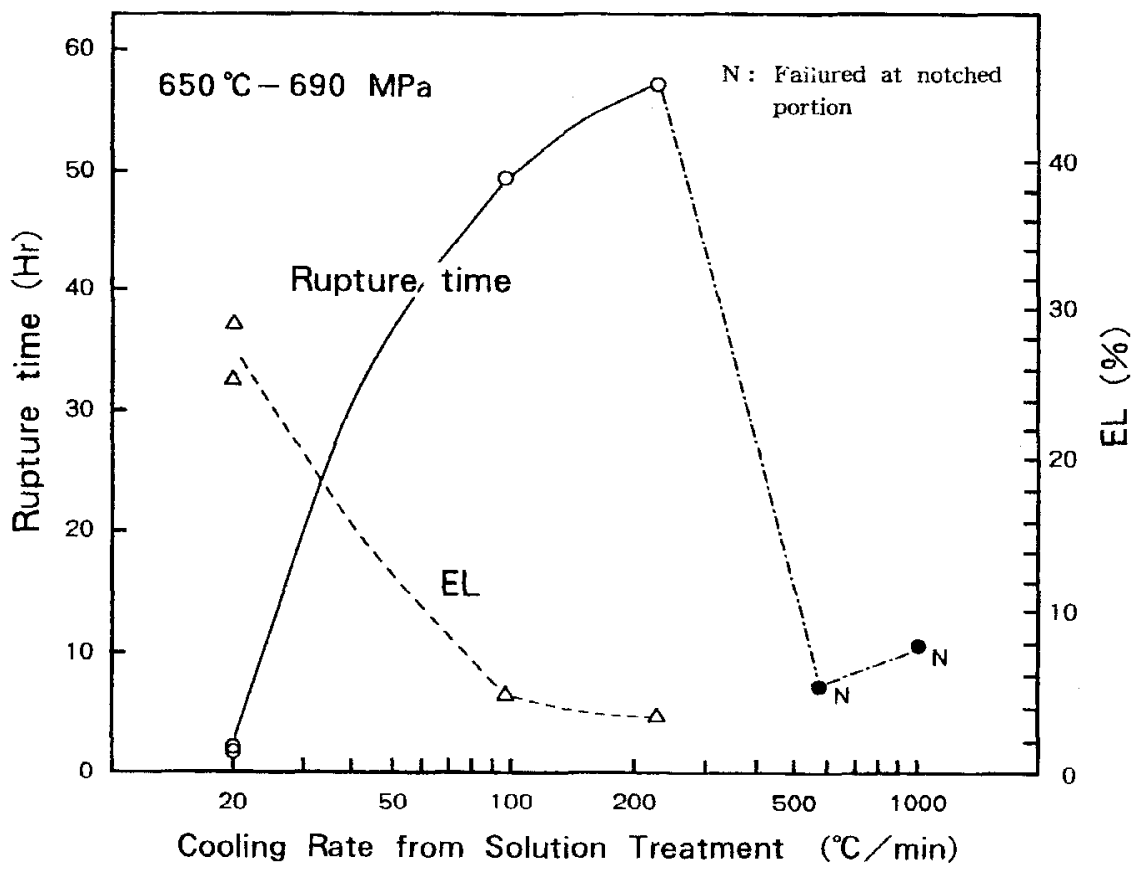

Figgure 7 Creep rupture properties with various cooling rate of Alloy 706 
specimen is relatively larger. The effect of grain size on creep rupture properties is also important. If the finer grain materials are tested, it seems that higher rupture strength and ductility will be obtained.

\section{Conclusions}

Effects of cooling rate from solution treatment temperature on mechanical properties and microstructures of a large Alloy 706 disk forging has been investigated. The results obtained are as follows.

1. The number and size of precipitates at the grain boundaries increased with incresing cooling rate from solution treatment temperature.

Microstructural observations showed that mixed delta and Eta phasees were present at the grain boundaries. The morphology of precipitates grow from globular type to cellular type and coarsed with incresing cooling rate.

2. The strength at room temperature increased with incresing cooling rate from solution treatment temperature. In addtion, the same tendency were observed in elongation, reduction of area and Charpy absobed energy.

3. The strength at elevated temperatures also increased with incresing cooling rate although the ductility at $650{ }^{\circ} \mathrm{C}$ was slightly decreased with cooling rate.

4. Creep rupture time at $650^{\circ} \mathrm{C}$ under $690 \mathrm{MPa}$ extended with increasing cooling rate, while creep rupture ductility decreased with incresing cooling rate. The notch detriodation took place in the case of the cooling rates which exceeds $300^{\circ} \mathrm{C} / \mathrm{h}$. It is concluded optimum cooling rate was between $50{ }^{\circ} \mathrm{C} / \mathrm{h}$ and $200^{\circ} \mathrm{C} / \mathrm{h}$.

\section{References}

1) P.W. Schlike, J. J. Pepe and R. C. Schwant "Advanced materials propel progress in land-based Gas Turbines " Advanced Materials and Processes, 4(1992), 22-30

2) P. W. Schlike, J. J. Pepe and R. C. Schwant " Alloy 706 metallurgy and Turbine Wheel Application" Superalloys 718,625 706 and derivatives, edited by E. A. Loria, The Mineral, Metals and Materials Society (1994) 1-12

3) Inconel Alloy 706, Huntington Alloys Products Division, Technical Brochure, The International Nickel Company Inc. (1974)

4) T. Honjo, O. Matsumoto, K. Morita, K. Hirose and M. Okamura, Manufacturing and "Mechanical Properties of a large size alloy 706 disk by ESR"

Superalloy 718,625,706 and Derivatives. The Minerals, Metals and Materials Society. 1994, p. 239-248

5) H.L.Eisenstein, "Properties of a fabricable high strength superalloy" Metals Engeering Quarterly, Nov. (1971) 20-25

6) K. A. Heck, "The Time-Temperature-Transformation Behavior of Alloy 706" Superalloys 718,625706 and derivatives, edited by E. A. Loria. The Mineral, Metals and Materials Society (1994) 393-404

7) J. Moll, G. Maniar and D Myuzika " Heat Treatment of 706 Alloy for Opt imum 1200 F Stress-Rupture Properties" Met. Trans. 2(1971)2153-2160 